\title{
Architectural Ensembles of the Cities-Plants of the Orenburg Province on the Example of the Katav Plants
}

\author{
Elena Ponomarenko, ${ }^{1, *}$
}

\begin{abstract}
${ }^{1}$ Scientific Research Institute of the Theory and History of Architecture and Urban Planning, branch of the Central Institute for Research and Design of the Ministry of Construction and Housing and Communal Services of the Russian Federation, Moscow, Russia

*Corresponding author. E-mail: evpon@mail.ru
\end{abstract}

\begin{abstract}
The relevance of the topic of this study is determined by society's growing interest in the architectural traditions of the regions of Russia. The article deals with the peculiarities of the emergence and development of cities-plants on the territory of the Orenburg province in the XVIII - XIX centuries on the example of the Katav plants. The author analyzes the historical periods of architectural and compositional formation of these settlements. On the basis of full-scale surveys and analysis of archival documents, printed and handwritten sources the layouts and development of this type of settlements are considered. The basic period of the formation of ensembles of the centers of these settlements - the beginning of the XIX century is considered in detail. Characteristic features of specific picturesque layouts of cities-plants and their strict dependence on the features of technological processes of metallurgical factories of that time are revealed.
\end{abstract}

Keywords: irregularity of the layouts of cities-plants, urban layout features, Katav plants

\section{INTRODUCTION}

The relevance of the research subject is determined by the fact that the importance of regions in Russia is steadily growing. Studying the principles of formation and features of layouts and city fabric of cities-plants allows expanding professional knowledge of architectsrestorers. Previously little-known data on the nature and regional features of these unusual settlements can serve as a basis for further research. The conclusions of this research will be important for the preservation and revival of the historic environment of the region's settlements.

The basic method of the research is the historicalarchitectural analysis and generalization of archival materials and the data acquired on site. The key methodological principle of the research is the system approach, which assumes the use of the historicalgenetic, architectural and town-planning analysis (the typological, stylistic analysis).

The main source of materials for this work is a fullscale survey of the territory of the modern Chelyabinsk region, which was part of the Orenburg province in the XIX century. The materials of the central and local archives and museums, including the documents of Berg-Kollegia (Ministry of Mining) and the Senate,

*Fund: This paper was funded by the Program of Fundamental Researches of the Ministry of Construction, Housing and Utilities of the Russian Federation and the Russian Academy of Architecture and Construction Sciences 2020, the Research Project 1.2.9. have been analyzed.

Exploration of cities-plants of the Ural Mountains began in the XVIII century, practically simultaneously with their construction. One of the most complete descriptions of the Ural and Siberian factories was compiled by Wilhelm de Gennin in the first half of the XVIII century. Velim Ivanovich Gennin, as he was called in Russia, describes the factories, their history, technology, economic situation and gives valuable practical guidance on metallurgical production. This is the first manual on mining and metallurgy, which has been compiled in Russia. The work includes a large number of illustrations [1]. Subsequently, V.I. Gennin's monograph was reprinted in 1937 as a single book [2]. Some Interesting works on the history of metallurgy in Siberia and the Urals belong to B.F.I. Herman [3]. Participants of building expeditions of I.K. Kirilov and V.S. Tatishchev in the general ethnographic works have left some descriptions of the cities-plants under construction. The most interesting works belong to: I.V. Kirilov [4], P.I. Rychkov [5, 6, 7], P.S. Pallas [8], I.I. Lepekhin [9], V.N. Vitevsky [10], A, E. Alektorov [11].

Modern architectural town-planning researches of cities-plants have been conducted by N.S.Alferov and reflected in his monograph "Architects of Old Ural. The First Half of The XIX Century" [12]. As well as in the collective monograph section of the Scientific Research Institute of the Theory and History of Architecture and Urban Planning [13]. A number of interesting studies on this topic are present in the works of R.M. Lotareva $[14,15]$. The most significant of which is the 
monograph "Cities-Plants of Russia. XVII - the first half of the XIX century [16]. Various aspects of the peculiarities of the planning and formation of the architectural environment of the cities-plants are considered in the works of V.A. Kolyasnikov [17], V.A. Matveev [18], N.N. Lyaptseva [19], A.A. Starikov [20], V.M. Pozdnikin [21], G.S. Zaikin [22], A.F. Mukomolov [23, 24], A.M. Raskin [25], E.F. Shumilov [26] and others. All these works focus on cities-plants of Russia or Ural. However, there have been conducted no special researches devoted to urban planning and architectural features of cities-plants of Southern Ural Mountains. At the same time the Southern Ural Mountains organically included into the structure of the settlement system of Ural Mountains, had the specific conditions and features of formation of architectural and town-planning heritage among which it is necessary to recall historical and economic features of the development of the region, natural conditions, etc.

\section{CONSTRUCTION OF CITIES-PLANTS IN THE SOUTHERN URALS}

Full-scale foundations of the metallurgical industry of the Urals were laid as early as during the reign of Peter the Great. Construction of iron-making and ironsmelting plants has begun at the end of the XVII - the beginning of the XVIII century. Cities-plants of Kamensky and Nevyansky appeared on the basis of ferrous metallurgical production in the Urals in 1701. At that time first small enterprises for iron and copper ore development appear in the Eastern Urals. By the time of the foundation of such a large settlement as Ekaterinburg, which has been a city-plant and a fortress at the same time in 1723, there have been twelve metallurgical and six copper smelting plants in the Urals. In the Orenburg province, the cities-plants appeared a little later - in the second half of the XVIII century, which contributed to the mining operations in the Russian province ("Fig. 1").

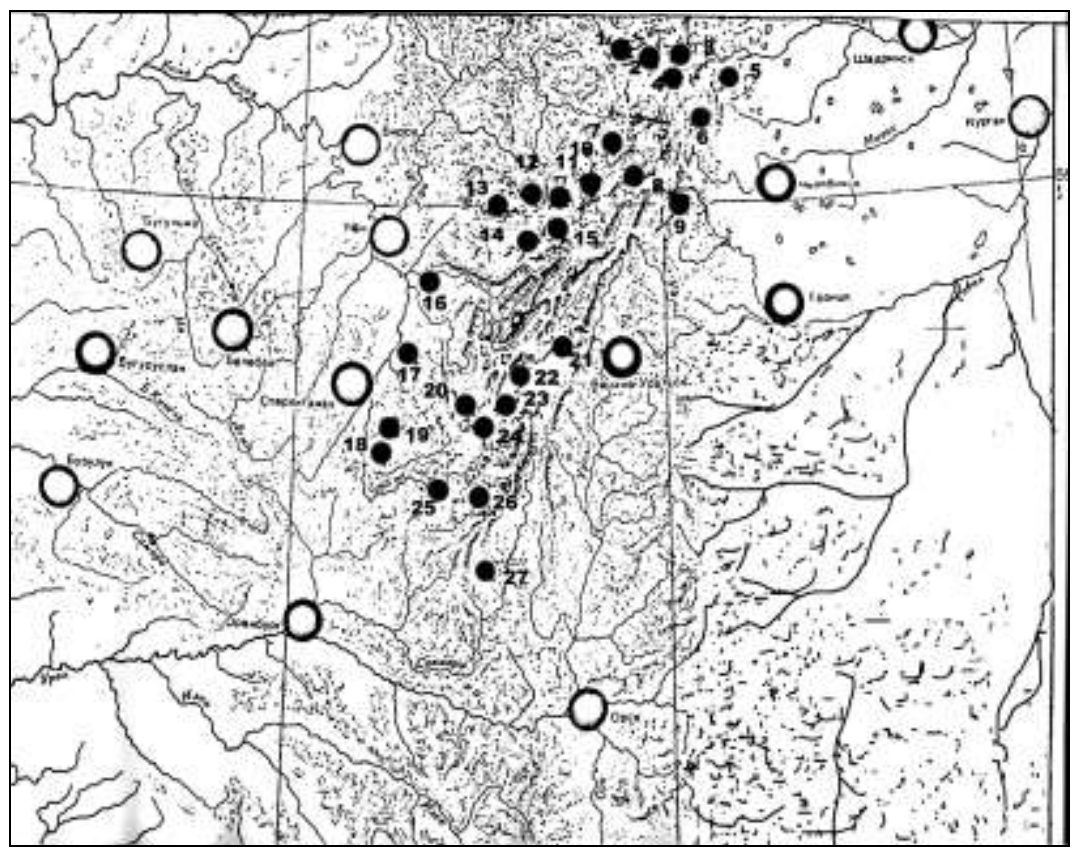

Fig. 1. Map of Orenburg province's plant towns.

\begin{abstract}
a. 1 - Nyazepetrovsk (1747), 2 - Verkhne-Ufaleyskiy plant (1761), 3 - Sukhovyaz plant (1778), 4 - Nizhne-Kyshtymskiy plant (1760), 5 - Kaslinskiy plant (1752), 6 - Verkhne-Kyshtymskiy plant (1757), 7 - Kusinskiy plant (1778).), 8 - Zlatoustoustovskiy (1754), 9 - Miasskiy copper plant (1766), 10 - Satkinskiy plant (1757), 11 - Minskiy plant (1779), 12 - Ust-Katav plant (1759), 13 - Simskiy plant (1758), 14 - Katav-Ivanovskiy plant (1759).), 15 - Yuriuzanskiy plant (1758), 16 - Arkhangelskiy plant (1753), 17 - Bogoyavlenskiy plant (1752), 18 - Voskresenskiy plant (1745), 19 Verkhotorskiy plant (1759), 20 - Verkhniy Avzyano-Petrovskiy plant (1755).), 21 - Beloretskiy plant (1762), 22 - Uzyanskiy plant (1772), 23 - Kaginskiy plant (1769), 24 - Nizhniy AvzyanoPetrovskiy plant (1756), 25 - Voznesenskiy plant (1755), 26 - Kanannikolskiy plant (1751), 27 - Preobrazhenskiy plant (1750)

There have always been unusual types of settlements during different periods of the townplanning history of Russia. One of such phenomena of the XVIII - early XX centuries are the cities-plants. The author of this term is the Ekaterinburg scientist N.S. Alferov. The city-plant is a special type of settlement, which was formed around the waterpeculiar phenomenon in the urban planning of Russia in the XVIII century. Settlements of this type have also been present in other countries, although in a very limited number. The industrial revolution of the end of the XVIII century and the use of hard coal as fuel led to the spread of quite different town-planning forms, organized around factories.
\end{abstract} operating plant. Its layout is organically connected with the structure of the plant. Cities-plants was a large and
The territorial layout of the Ural factory settlements had its specific peculiarities. The level of the 
development of construction equipment at that time did not allow for the construction of dams on full-flowing rivers, while the water reserves of relatively small rivers and ponds were not sufficient to provide a driving force for the entire technological process of metallurgical production lines [27]. Therefore, there were cities-plants that have been built on territories where a small river flowed into a large one. A small river was blocked by a dam, and a large river served as a transport artery. It was more profitable to transport heavy loads through the water at that time.

The layout of any city-plant was unusual. It was based on the then-existing technology of metal smelting, which required the construction of a dam and a factory pond. The plant and the dam were located in the very center of the settlement and determined the main planning axes. One of them passed along the plant, and the second one was perpendicular to the first one. This rigid arrangement of axes led to the formation of a rectangular layout of the settlement. To some extent, the rectangular layout was created due to the fact that a large number of identical sites were allocated simultaneously for the construction of the residential area. The center of the settlement was the square where the main entrance to the plant, office building, factory owner's house, and other large buildings have been located. By the end of the 20s of the XIX century, there has been a need for the redevelopment of settlements. The residential area grew around a plant in a chaotic manner and required order. Features of the relief led to the appearance of radial directions of development in the planning.

\section{UST-KATAV PLANT}

Katav cities-plants were founded in 1775-1759 and included Katav-Ivanovsk and Ust-Katav.

Ust-Katav plant was founded as a small settlement near the plant. In 1837 the settlement included only two residential area blocks, which were located perpendicularly [28].

These two directions corresponded to the directions of the plant territory and the dam ("Fig. 2"). V.A. Vesnovsky notes the picturesque location of Ust-Katav and the presence of two parts of the settlement [29].

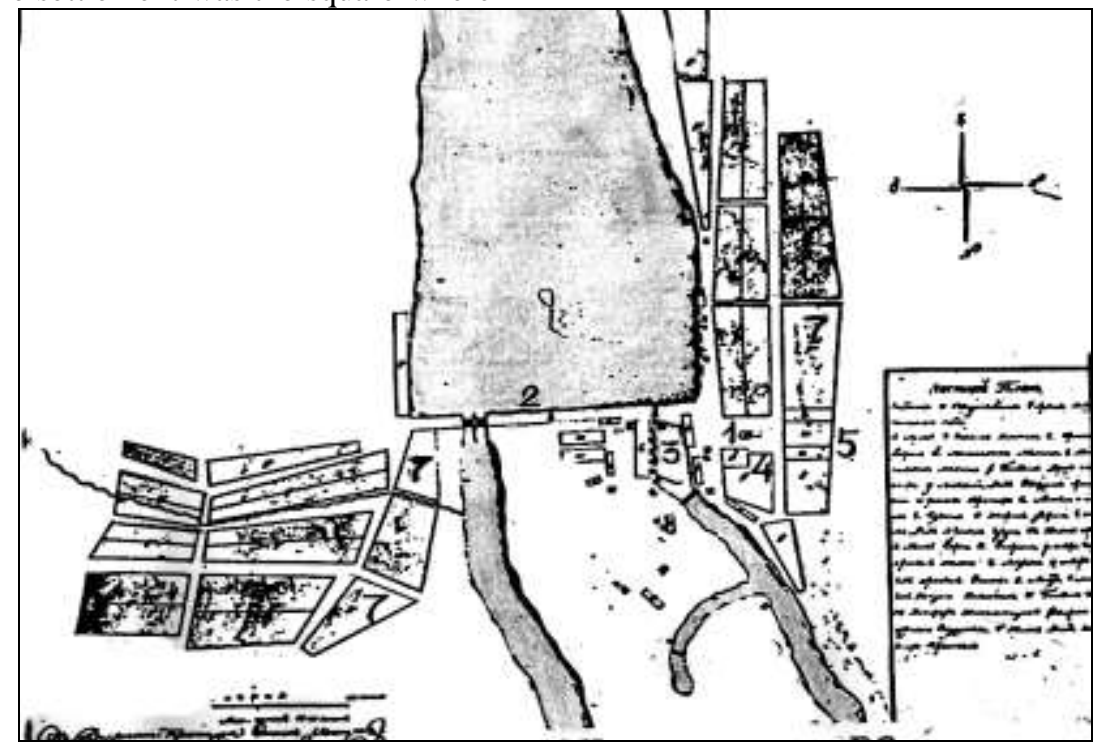

Fig. 2. Ust-Katav plan of 1837.

The central square of Ust-Katav was both a factory and a bazaar square. This area was occupied by the most significant buildings of the settlement and the main entrance to the plant. Not far from the square there was the Church of the Nativity of Christ, built in the middle of the XIX century. Nowadays the church is disfigured by reconstructions that have taken place during the Soviet period. Large additional volumes are present now on the northern side of the building ("Fig. 3").
- church, 2 - dam, 3 - plant, 4 - manor house and office, 5 - priest's house, 6 - flour mill, 7 - ordinary houses The mansion of Beloselsky-Belozersky - the owners of the factory in Ust-Katav was built in the middle of the XIX century in the classical style. The two-story building has a rectangular outline and a hip roof. The main entrance is located in the center of the main facade and is accentuated by an arched portico. The portico consists of four pilasters and three arches between them. The portico is completed with a terrace, over which there is a canopy resting on round metal posts. The corners of the building on the ground and 
first floor are decorated with pilasters. The ground floor and a portico have decorative plaster quoins. There are five rectangular windows with decorative triangular pediments above them on the first floor of the main facade. The windows of the ground floor have keystones. The building is completed with a profiled cornice under which a horizontal belt passes at a certain distance. The building is currently in a dilapidated state. The ordinary buildings of Ust-Katav of the XVIII - the first half of the XIX century were represented by wooden huts, which is typical for the majority of citiesplants. The outbuildings and foundations were often made of limestone.

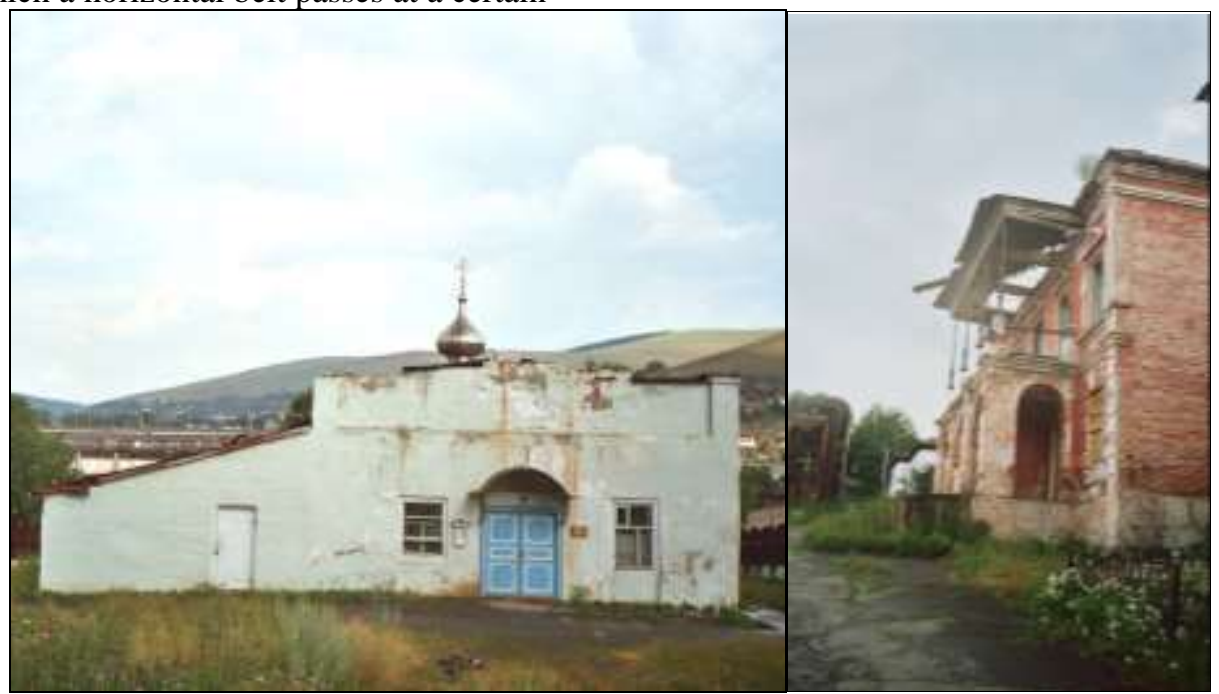

Fig. 3. Ust-Katav buildings of the beginning of XIX century: church, breeder's mansion.

At the end of the XIX century, Ust-Katav remained a large settlement. It became a railway station, and the plant filled orders for the railway. The layout of the village and its boundaries remained the same as in the previous period. The natural environment was the main expressive feature of the town. "The plant lies in the gorges of high mountains at the confluence of the Katav river into the Yuriuzan River" [30].

The architectural ensemble of the city center changes. The city fabric of Ust-Katav during the period under consideration has been characterized by its diversity. In the city center, except for wooden houses, there were many stone and brick houses. Construction materials have been often combined. For example, figured brick architraves and patterned cornices with stepped icicles could be used in the house made of rubble stone. Brick houses have often been plastered. There are examples with plastered low ground floor and the main first floor completed with figured brickwork. The facades were decorated with brick pilaster strips and wide cornices with stepped icicles. The floors were separated by wide profiled horizontal belts with niches and protrusions inside. There were one-story stone and plastered houses with figured platbands.

But the majority of stone mansions were two-story plastered buildings with four-gable roofs. For example, the mansion near the church has simple windows, completed with a three-centered arch, the upper floor of the mansion on the other side of the dam has decorative plaster quoins and windows with figured platbands. Its profiled cornice is decorated with an additional ornamental ribbon.

\section{KATAV-IVANOVSKIY PLANT}

Katav-Ivanovskiy plant is located in a picturesque place. "Katav-Ivanovskiy plant was surrounded by the highest mountain ranges in the Urals, the nearest one of which was around thirty versts away" [31].

According to the description of P.I. Rychkov made in the XVIII century: "...there were two blast-furnace houses there for the melting of cast iron... 370 peasant households have been purchased and settled. There was also the Church in the name of John the Baptist" [32]. The lithograph depicting the plant at the period right after its foundation showed it as a small village with three parallel streets and sidestreets perpendicular to them. There was only one residential block, which was located along the pond. The church was located on the factory square ("Fig. 4").

At the beginning of the XIX century, the plant was considerably improved. I.I. Lepekhin notes that the Katav-Ivanovskiy plant was built "on the river Katav" [33]. The ensemble of the center of the city-plant formed gradually, mainly in the XIX century. The Church of St. John the Baptist in Katav-Ivanovsk was built in the 20s of the XIX century. The type of church is unusual, as it carries the influence of Catholic 
churches. In general, the building belongs to the mature classicism with elements of Baroque in its decoration. Before the destruction and reconstruction in 1929, it was a three-nave basilica. The western facade had two bell towers that flanked the classic Doric four-column portico with a pediment.

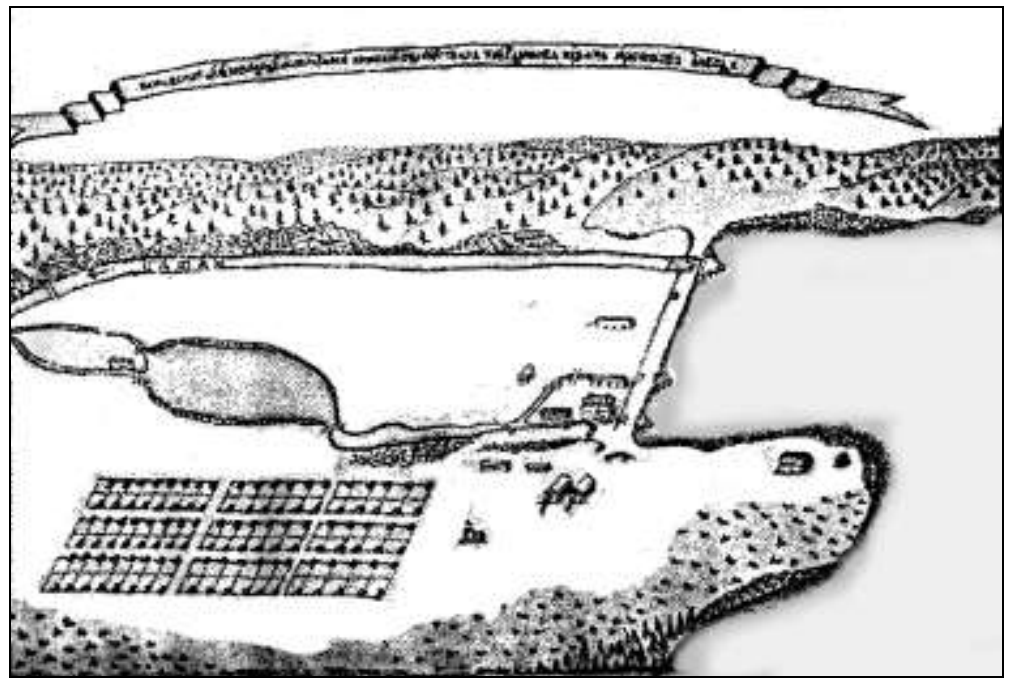

Fig. 4. General view of the Katav-Ivanovskiy plant in 1760 (lithograph of the XIX century).

The mansion of Beloselsky-Belozersky, who have owned the factory for more than a hundred years, was built in 1829 in the style of Classicism. Knyaz A.M. Beloselsky-Belozersky, who married the granddaughter of one of the first owners of the plant, I.S. Myasnikov, was a man well educated for his time. In 1809, he handed over his South Ural estate with the Katavsk and Yuriuzan factories to his son Esper Aleksandrovich, who has built the house. The two-story mansion, located on Nikolskaya Street, had a garden behind the main building. The main facade is accentuated by a wide, strongly protruding central risalit with an arcade on the ground floor. The arcade consists of three arches resting on metal columns. Metal columns are very unusual for Russia. They resemble the "French order (colomne Françoise)" by Filibert Delorme, in which, as the researchers claim, "the architect, rethinking the Renaissance and Gothic styles, complements the ancient order with new elements" [34]. Columns of the mansion have strongly loosened abacas, consisting of shelves, instead of capitals ("Fig. 5"). The base of the columns includes two plain belts, with horizontal straps on their upper and lower parts. Between these belts, the trunk of the column has fluting.

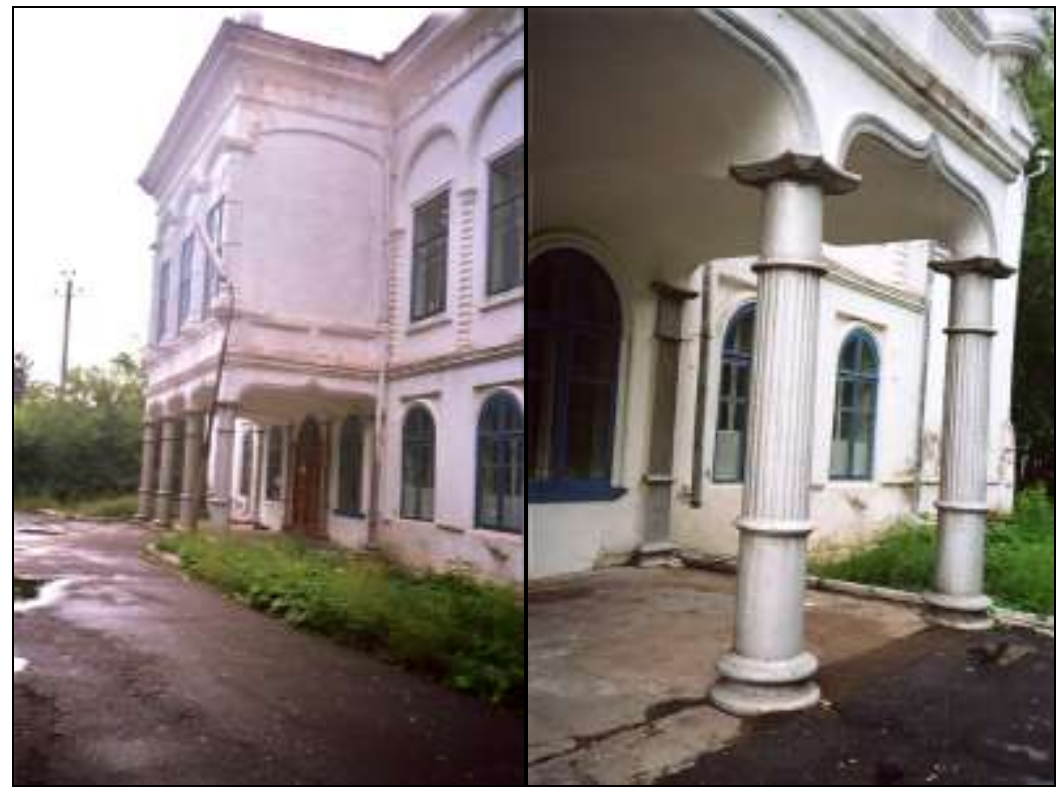

Fig. 5. Beloselsky-Belozerskiy Estate in Katav-Ivanovsk. 
The arches are highlighted by modest archivolts. The ground floor is separated from the first floor by two profiled horizontal belts, the upper one of which is located at the bottom of the windows of the first floor. These windows have a rectangular shape. There are half columns similar to those of the arcade, but with several straps between them. Half columns are connected by semi-circular overhead arches, which together form peculiar window niches. The windows Inside the niches are decorated with two more semi-circular superimposed niches. The upper part of the risalit is completed with a frieze and a strongly protruding profiled cornice as well as the entire facade. The side planes of the first floor of the risalit are decorated with a three-center superimposed arches. On the ground floor behind the arcade in the main facade plane, there are windows and a door with semi-circular completion. Between them, there are fluted pilasters. The door has a rectangular opening with a tympanum. The planes of the main facade, flanking the risalit, have rectangular windows with flat casing framed by twisted columns, which rest on the superimposed profiled arches. On the rest of the main facade and the side facades of the building, columns have twisted trunks. From the east, a building with a much more modest decor has been later added to the building. Nowadays, the mansion houses a museum. The ordinary residential development of Katav-Ivanovsk was similar to that of Ust-Katav. The peculiarity of these buildings was the location of a number of streets on the precipice, which gives a special picturesque quality to the positioning of wooden houses. From the middle of the XIX century, stone houses began to appear in the center of the city.

In the XIX century, the plant successfully operated and was considered to be thriving due to the production of rails. After the railway stopped placing orders, it fell into disrepair and was closed in 1907. The desolation is clearly described in Dobrohotov's guidebook. "At the entrance to the Katavskiy factory the eye catches a huge settlement: a number of streets stretch along the mountain, there are several churches, huge factory pipes rise near the dam, there are rows of factory buildings, but they are abandoned, silent, as if yearning for the past, when life was in full swing. Even the factory's pond has been lowered, and on its place, a flat, muddy space has appeared" [35]. There were 10 thousand inhabitants in the city. The development of the center was significantly renewed, although the boundaries of Katav-Ivanovsk practically did not change.

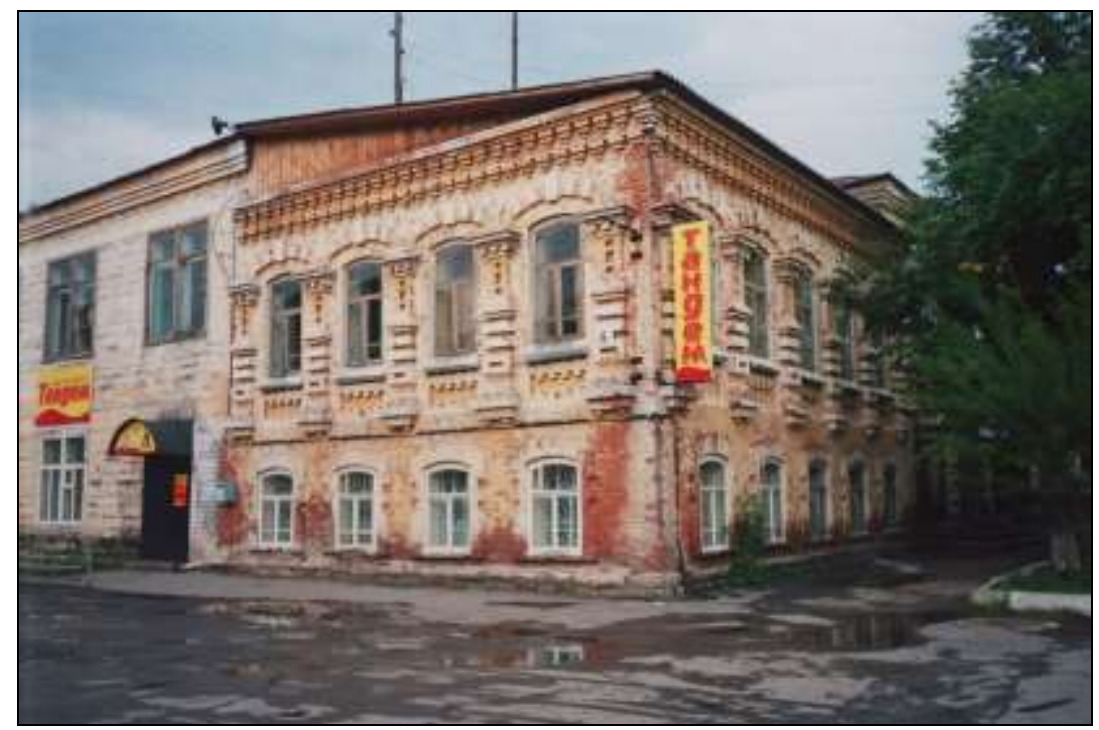

Fig. 6. The mansion of N.N. Tsyganov in Katav-Ivanovsk.

An early example of the eclecticism of style is the mansion of the hardware manufacturer N.N. Tsyganov in Katav-Ivanovsk, which belongs to the 40s of the XIX century ("Fig. 6"). The appearance of such artwork was due to the South Urals tradition of decorating facades with figured brickwork. It is no coincidence that the double ornament of the cornice in the form of stepped icicles, typical for the region, is applied here. The building is two-story, with a high first floor which has rectangular windows with three-center arch completion.
The windows are enclosed in a single ornamental frame, consisting of figured pilaster strips, connected over the windows by rusticated three-center arches with emphasized keystones. Pilaster strips cut in the lower part of the strip with horizontally stretched niches with dentils between the pilasters, which separate the ground and the first floors. The ground floor is lower and has windows of the same shape decorated with flat casing with dentils. 


\section{CONCLUSION}

Thus, the cities-plants of the Orenburg Province, founded later in the North and Central Urals, were characterized by less regular structure. These settlements were not large in this province. Natural elements such as mountains and water areas played a significant role in the formation of the settlement panoramas. The urban planning basis of the citiesplants is the functional organization of metallurgical production corresponding to the historical period. It is necessary to consider the formation of a local residential area in this context.

Settlements appeared simultaneously along with or right after the construction of industrial buildings. Administrative and cult buildings, residential houses for administration and workers of the plant have been built in close proximity to the factory site. Located, as a rule, not on the steep bank, but on the lowered territories, the cities-plants included a pond and a non-navigational river in their structure. The territory of factories and factory premises with the owner's manor, office and other public buildings formed the centers of settlements. The central squares of the cities-plant, which were not particularly large, were often factory, church, and bazaar squares at the same time.

The development of prefabricated towns included both traditional and "model" houses. Stylistically, the architecture of the cities-plants passed all the same stages of development as the architecture of Russia as a whole, but in some cases, there was a delay in the emergence of new directions. In the second half of the XIX - beginning of the XX century, the construction of railways began to have a significant impact on the formation of cities-plants.

\section{References}

[1] V.I. Gennin, Mountain History, The Outlines of the Naturalities and Minerals and Other Curiosities of the Chambers of the Siberian Mountain and Factory Districts, both Renovated Old and Newly Built Mountain and Factory Buildings Collected by the Lieutenant General of Artillery and Cavalier of the Order of St. Alexander, George Wilhelm de Gennin (Gornaya Istoriya, General-Leytenantom Ot Artillerii I Kavalerom Ordena Sv. Aleksandra, Georgiem Vilgelmom De-Genninym, Sobrannaya Naturalii I Mineralii Kamer V Sibirskih Gornyh I Zavodskih Distriktah, Takzhe Chrez Ego O Vnov Stroennyh I Staryh Ispravlennyh Gornyh I Zavodskih Stroeniyah I Prochih Kurioznyh Veshchah Abrisy). Mountain Journal (Gornyy Zhurnal), 1828, Book 7, pp. 113-140; Book 8, pp. 69-87; Book 9, pp. 113-140; Book 10, pp. 83-99; Book 11, pp. 83-108; Book 12, p. 12, pp. 43-71 [in Russian].

[2] V.I. Gennin, Description of Ural and Siberian Plants (Opisanie Uralskih I Sibirskih Zavodov), Moscow, State Publishing House "History of Plants" ("Istoriya Zavodov"), 1937 [in Russian].

[3] I.F. German, Essays on Siberian Mines and Factories, Collected by Court Counselor and Academician Ivan German (Sochineniya O Sibirskih Rudnikah I Zavodah, Sobrannye Nadvornym Sovetnikom I Akademikom Ivanom Germanom),
Ch. 1-3. St. Petersburg: Imperial Academy of Sciences (Imperatorskaya Akademiya Nauk), 1797 - 1801 [in Russian].

[4] I.K. Kirilov, The Blossoming of the All-Russian State (Cvetushchee Sostoyanie Vserossiyskogo Gosudarstva) Moscow: Nauka, 1977 [in Russian]

[5] P.I. Rychkov, History of Orenburg (1730-1750) (Istoriya Orenburgskaya (1730-1750)), Orenburg: Provincial State Committee Publishing House, 1896 [in Russian].

[6] P.I. Rychkov, Topography of the Orenburg Province (Topografiya Orenburgskoy Gubernii), St. Petersburg: Printing House of P.P. Soikin, 1762 [in Russian]

[7] P.I. Rychkov, Topography of the Orenburg Province (Topografiya Orenburgskoy Gubernii), Orenburg: Provincial State Committee Publishing House, 1887, p. 399 [in Russian].

[8] P.S. Pallas, Journey to Different Provinces of The Russian State (Puteshestvie Po Raznym Provinciyam Rossiyskogo Gosudarstva), part 2. St. Petersburg: Publishing House of the Imperial Academy of Sciences, 1786 [in Russian].

[9] I.I. Lepekhin, Continuation of The Daily Notes of Ivan Lepekhin's voyage in 1771 (Prodolzhenie Dnevnyh Zapisok Puteshestviya Ivana Lepekhina V 1771 Godu), St. Petersburg: Imperial Academy of Sciences, 1814, p.285 [in Russian].

[10] V.A. Vitevsky, I.I. Neplyuev and the Orenburg Region in Its Former Composition Before 1758 (I.I. Neplyuev I Orenburgskiy Kray V Prezhnem Ego Sostave Do 1758 Goda), Vol. 1, Kazan Typolitography of Klyuchnikov V.M., 1897 [in Russian].

[11] A.E. Alektorov, History of the Orenburg Province (Istoriya Orenburgskoy Gubernii) - Orenburg: Printing House of Breslin, 1883 [in Russian].

[12] N.S. Alferov, Architects of the Old Urals. The First Half of the XIX Century (Zodchie Starogo Urala. Pervaya Polovina XIX Veka), Yekaterinburg: Sverdlovsk Book Publishing House, 1960 [in Russian].

[13] St. Petersburg and Other New Russian Cities of the XVIII First Half of the XIX century (Peterburg I Drugie Novye Rossiyskie Goroda XVIII - Pervoy Poloviny XIX Veka), ed. by Gulianitsky N.V. Moscow: Stroyizdat, 1993 [in Russian].

[14] R.M. Lotareva, Cities-Plants of Russia. XVII - First Half of the XIX Century (Goroda-Zavody Rossii. XVII - Pervaya Polovina XIX Veka), Yekaterinburg: Ural University Publishing House, 1993 [in Russian].

[15] R.M. Lotareva, Industrial Urban Planning (Promyshlennoe Gradostroitelstvo), Yekaterinburg: Publishing House of the Ural University, 1996 [in Russian].

[16] R.M. Lotareva, Cities-Plants of Russia. XVII - First Half of the XIX Century (Goroda-Zavody Rossii. XVII - Pervaya Polovina XIX Veka), Moscow: Socrat Publishing House, 2011 [in Russian].

[17] V.A. Kolyasnikov, Reconstruction of Historical Centers of the Ural Cities-plants in the Conditions of Security Zoning (Rekonstrukciya Istoricheskih Centrov Gorodov-Zavodov Urala $\mathrm{V}$ Usloviyah Ohrannogo Zonirovaniya), Issues of Industrial Urban Development (Voprosy Promyshlennogo Gradostroitelstva): Interuniversity collection of scientific works. Edited by Starikov A.A., Lotareva R.M., Kuleshova L.A. Yekaterinburg: Architecton, 1992, pp. 132-150 [in Russian].

[18] V.A. Matveev, Architecture of the Urals in the XVIII Century (Arhitektura Urala XVIII Veka), Leningrad: Prosveschenie, 1952 [in Russian].

[19] N.N. Lyaptsev, Planning and Layout of The Fortress-City of Verkhoturye (Planirovka I Zastroyka Goroda-Krepost Verhoturya), Issues of Architecture and Urban Planning (Voprosy Arhitektury I Gradostroitelstva), Sverdlovsk: Sredneuralsk Book Publishing House, 1970, pp. 15-16 [in Russian] 
[20] A.A. Starikov, Silver Ring of the Urals (Serebryanoe Kolco Urala), Yekaterinburg: Socrat Publishing House, 2011 [in Russian].

[21] V.M. Pozdnikin, Famous Architectural Monuments of the Sverdlovsk Region (Znamenitye Pamyatniki Arhitektury Sverdlovskoy Oblasti), Yekaterinburg: Socrat Publishing House, 2007 [in Russian].

[22] G.S. Zaikin, Study, Generalization of Practice and Development of Methods and Techniques for the Formation of Architectural Ensembles and Complex Development of Architectural and Spatial Environment of the Historical "Cities-Plants" of the Urals, Taking Into Account the Preservation of their Individual Characteristics (Izuchenie, Obobshchenie Praktiki I Razrabotka Priemov I Metodov Formirovaniya Arhitekturnyh Ansambley I Kompleksnogo Razvitiya Arhitekturno-Prostranstvennoy Sredy Istoricheski Slozhivshihsya «Gorodov-Zavodov» Urala S Uchetom Sohraneniya Ih Individualnyh Osobennostey), Sverdlovsk: Publishing House of the Sverdlovsk Architectural Institute, 1985 [in Russian].

[23] A.F. Mukomolov, At the South Urals Plants (Na Yuzhnouralskih Zavodah), Vol. 1, Moscow: Territorya Publishing House, 2001 [in Russian].

[24] A.F. Mukomolov, At the South Urals Plants (Na Yuzhnouralskih Zavodah), Vol. 2, Moscow: Territorya Publishing House, 2001 [in Russian].

[25] A.M. Raskin, Classicism in the Monuments of the Sverdlovsk Region (Klassicizm V Pamyatnikah Sverdlovskoy Oblasti), Yekaterinburg: Ural State Academy of Architecture and Art, 2007 [in Russian].

[26] E.F. Shumilov, From the History of Izhevsk, Udmurtia and Russia (Iz Istorii Izhevska, Udmurtii I Rossii), Izhevsk: Udmurt State University, 2008 [in Russian].

[27] I.K. Kirilov, The Atlas of the All-Russian Empire: Collection of I.K. Kirilov's Maps. Reprint Edition (Atlas Vserossiyskoy Imperii: Sobranie Kart I. K. Kirilova. Reprintnoe Izdanie), St. Petersburg: Alpharet Publishing House, 2008 [in Russian].

[28] Russian State Historical Archive, F.37, Inv.63 f. 57., p.2.

[29] V.A. Vesnovsky, Guide to the Urals (Putevoditel Po Uralu), Yekaterinburg: Vesnovsky, 1904, p.324 [in Russian].

[30] A.I. Dmitriev-Mamonov, From the Volga to the Great Ocean. Guide to the Siberian Railway, (Ot Volgi do Velikogo okeana. Putevoditel po Sibirskoy Zheleznoy Doroge), St. Petersburg: Ministry of Railways, 1900, p.82 [in Russian].

[31] I.I. Lepekhin, Continuation of The Daily Notes of Ivan Lepekhin's voyage in 1771 (Prodolzhenie Dnevnyh Zapisok Puteshestviya Ivana Lepekhina V 1771 Godu), St. Petersburg: Imperial Academy of Sciences, 1814, p.285 [in Russian].

[32] P.I. Rychkov, Topography of the Orenburg Province (Topografiya Orenburgskoy Gubernii), Orenburg: Provincial State Committee Publishing House, 1887, p. 399 [in Russian].

[33] I.I. Lepekhin, Notes on the Voyage of Academician Ivan Lepekhin (Zapiski Puteshestviya Akademika Ivana Lepekhina), St. Petersburg: Imperial Academy of Sciences, 1821, p.283 [in Russian].

[34] E.A. Efimova, The Importance of Decor in The Process of The Formation of The Renaissance Style in French Architecture (Znachenie Dekora V Processe Formirovaniya Renessansnogo Stilya Vo Francuzskoy Arhitekture), Bulletin of Moscow University (Vestnik Moskovskogo Universiteta), Issue: History, №8 1989, pp. 31-41 [in Russian].

[35] F.P. Dobrohotov, North, Middle and South Ural (Ural Severnyy, Sredniy i Yuzhnyy), St. Petersburg: B.A. Suvorin Printing House, 1917, p.550 [in Russian]. 